\title{
COUNTERMAJORITARIAN INSTITUTIONS \\ IN THE RUSSIAN CONSTITUTION OF 1993 AS AN INSTRUMENT ENSURING CONSTITUTIONAL AND POLITICAL STABILITY
}

\author{
SERGEY SHAKHRAY, \\ Lomonosov Moscow State University (Moscow, Russia) \\ SVETLANA POPOVA, \\ Institute of Socio-Political Research of the Russian Academy of Sciences \\ (Moscow, Russia)
}

DOI: $10.21684 / 2412-2343-2017-5-1-78-92$

The article enriches the discussion on the legal reasons and conditions fostering the viability of democratic constitutions by analyzing the rich experience of the Russian Constitution of 1993. Particular attention is paid to the concept of countermajoritarian institutions. The authors elaborate the idea that countermajoritarian institutions can play an important role in ensuring the viability (put in other terms, the proper balance between stability, adaptability, and dynamic development) of modern democratic constitutions as well as political regimes.

The article presents evidence-based data showing that the President and the Constitutional Court of the Russian Federation systematically acted as countermajoritarian institutions at the initial stage of the implementation of the "blueprint for the future" set down in the 1993 Russian Constitution. As a result of the activities of these institutions, strong legal frameworks were created that are necessary for the establishment of a new constitutional system of the Russian state and law.

Today, the Russian Constitution of 1993 is one of the longest lasting democratic constitutions in the world (the average "life expectancy" of democratic constitutions adopted over the past 250 years is about seventeen years). The study of the countermajoritarian provisions in the 1993 Russian Constitution is of both theoretical and practical importance. In particular, the results of the study can be useful in creating efficient legal instruments for the maintenance of political stability and social development management both within sovereign states and within interstate communities. 
Keywords: constitutional law; constitutional court; countermajoritarian institutions; constitutional stability; president; Russian Constitution.

Recommended citation: Sergey Shakhray \& Svetlana Popova, Countermajoritarian Institutions in the Russian Constitution of 1993 as an Instrument Ensuring Constitutional and Political Stability, 5(1) BRICS Law Journal 78-92 (2018).

\section{Table of Contents}

\section{Introduction}

\section{Starting Point: The Concept of Countermajoritarian Institutions}

2. Countermajoritarian Institutions in the Russian Constitution of 1993

3. The President and the Constitutional Court as Institutions Fostering the Implementation of Constitutional Ideas

4. The Constitutional Court: Applying the Framework Conclusion

\section{Introduction}

Studies on the factors and mechanisms ensuring a political system's stability in the situation of major changes, determined both internally (reforms, modernizations) and externally (global crises, revolutions), comprise one of the most topical global issues of the second half of the $20^{\text {th }}$ and the early $21^{\text {st }}$ century. Today's world has entered an era of instability and profound transformations whose future outcome is thus far unclear. In this context, the requirements of prognostic value and the practical usefulness of knowledge of the legal sciences, as well as the humanities, for improving the effectiveness of social development management become significantly more demanding.

This paper proceeds from ideas about the fundamental role of constitutional models and institutions in managing social transformations. Another starting point is the concept of the countermajoritarian institution. It assumes that modern social systems have special legal and political mechanisms which can "correct" the decisions of the majority adopted in a lawful, democratic procedure. These mechanisms come into action when the majority decision harms the interests of the State and society or violate citizens' rights and freedoms.

The experience of major changes in the world in recent decades provides a wealth of empirical material that enables the theoretical conceptualization of the place and role of constitutions in managing social transformations. In Russia, it has been shown that the viability of the Constitution of 1993 is the main prerequisite for the 
successful implementation of the strategic "blueprint for the future" enshrined in the constitutional provisions. ' Here, "viability" means a combination of sustainability and development. Put in other terms, a viable constitution must have special mechanisms to ensure its long-term stability and the realization of its creative potential.

According to some international authors (e.g. Adam Przeworski, Larry Diamond, Barry R. Weingast, Juan J. Linz, Alfred Stepan), ${ }^{2}$ among the most important conditions for ensuring a constitution's stability are its special internal design and the firm conviction among different groups of the general public and politicians that conforming to constitutional principles promotes their own interests. These conclusions were made in the 1990s when the transformation processes in Eastern Europe and post-Soviet space were far from completion and the West's faith that liberal values would be automatically adopted by any society that had embarked on the path to modernization had not wavered yet. However, the democratic transition experience of Russia and other countries has demonstrated that, even in the absence of sustainable interest in the preservation of the constitution on the part of the majority of the general public and political elites, the Basic Law could remain stable and viable while the ideas, principles, and models enshrined in it could effectively change the social and political reality. This is what the institutions such as the Constitutional Court and the Head of State exist for. Among other things, these institutions can play the role of a countermajoritarian instrument.

\section{Starting Point: \\ The Concept of Countermajoritarian Institutions}

One of the best known themes in the American theory of constitutional law is "countermajoritarian difficulty" (sometimes referred to as "countermajoritarian dilemma"). It was first described by Alexander M. Bickel, ${ }^{3}$ a professor at Yale Law School, who maintained that judicial review is illegitimate because, in his opinion, it makes the will of the judges who have not been democratically elected superior to the will of the democratically elected legislative body that represents the people's majority.

\footnotetext{
See, e.g., Sonia Mittal \& Barry R. Weingast, Self-Enforcing Constitutions: With an Application to Democratic Stability in America's First Century, 29(2) Journal of Law, Economics, and Organization 278 (2013); Шахраŭ С.М. О Конституции: Основной закон как инструмент правовых и социально-политических преобразований [Sergey M. Shakhray, Towards the Constitution: The Basic Law as an Instrument for Legal and Socio-Political Change] (Moscow: Nauka Publishing House, 2013).

2 See Adam Przeworski, Democracy and the Market: Political and Economic Reforms in Eastern Europe and Latin America (New York: Cambridge University Press, 1991); Larry Diamond, Developing Democracy: Toward Consolidation (Baltimore: Johns Hopkins University Press, 1999); Juan J. Linz \& Alfred Stepan, Problems of Democratic Transition and Consolidation (Baltimore: Johns Hopkins University Press, 1996); Barry R. Weingast, The Political Foundations of Democracy and the Rule of Law, 91 (2) American Political Science Review 245 (1997).

3 Alexander M. Bickel, The Least Dangerous Branch: The Supreme Court at the Bar of Politics $\left(2^{\text {nd }}\right.$ ed., New Heaven and London: Yale University Press, 1986).
} 
Such an approach to interpreting the meaning of democratic legitimacy, however, is formal, stemming from the understanding of democracy in a narrow, procedural sense only, as the implementation of the will of the majority. In spite of its majoritarian nature, the meaning of democracy is much wider than mere mathematical calculations, since true democracy is based on a complicated set of ideas and principles the most important of which are the guarantees of citizens' rights, freedoms, and equality, including minority rights.

When a judge argues against an adopted law in order to protect citizens' rights and freedoms guaranteed by the constitution, he or she acts democratically, thus putting the democratic ideas and principles into practice.

Moreover, there are quite a few instances when democratically elected representatives pass legislation that does not actually reflect the people's will, and in such cases judicial review of the adopted legal acts is the only acceptable way to correct the "failures of democracy."

In 2008, John E. Jones III, a U.S. federal judge, declared that Art. 3 of the U.S. Constitution (which describes the U.S. court system) is, in essence, countermajoritarian, establishing the right of the judicial branch to act against the will of the majority. He wrote,

The judicial branch protects against the tyranny of the majority. We are a bulwark against public opinion. And that was very much done [enshrined in the U.S. Constitution] with a purpose, and I think that it really has withstood the test of time. The judiciary is a check against the unconstitutional abuse and extension of power by the other branches of government. ${ }^{4}$

In fact, it is the countermajoritarian institutions of the State that comprise one of the pivotal mechanisms to ensure the constitution's stability and facilitate its proper implementation.

In the early $21^{\text {st }}$ century, American political scientists, who have not yet given up the idea of creating a universal model of the constitution that would be able to guarantee the successful democratic transformation of authoritarian regimes, have focused on identifying conditions fostering the viability of democratic constitutions. ${ }^{5}$ As a result, the experts arrive at the conclusion that many examples of successful

4 Judge John E. Jones III, Inexorably toward Trial: Reflections on the Dover Case and the "Least Dangerous Branch," The Humanist, 17 December 2008 (Feb. 11, 2018), available at https://thehumanist.com/ magazine/january-february-2009/features/inexorably-toward-trial-reflections-on-the-dover-caseand-the-least-dangerous-branch.

5 See Zachary Elkins et al., The Endurance of National Constitutions (New York: Cambridge University Press, 2009); Susan Alberts et al., Democratization and Countermajoritarian Institutions Power and Constitutional Design in Self-Enforcing Democracy in Comparative Constitutional Design (T. Ginsburg (ed.), Cambridge: Cambridge University Press, 2012). 
democratization are associated with using specific countermajoritarian institutes, as well as with "appropriately designed" countermajoritarian provisions set down in the constitutions. ${ }^{6}$ Where necessary, those countermajoritarian mechanisms impose restrictions on the will of the elected majority.

For example, according to Susan Alberts, Christopher Warshaw, and Barry R. Weingast, a bad choice of the formula to calculate pro-rata representation in the electoral legislation can be beneficial for the former authoritarian elite. This risk, however, can be offset by the presence of an upper house of the parliament that represents regions, or by other power institutions that are capable of vetoing the majority's decisions.' Or, as Weingast notes in a recent article, a necessary condition to support the market economy is

a critical set of countermajoritarian provisions [that] include the rule of law, protection of property rights, and enforcement of contracts and justice more generally. ${ }^{8}$

\section{Countermajoritarian Institutions in the Russian Constitution of 1993}

The conclusions put forward by the American researchers appear quite obvious to the modern Russian school of constitutional design, which, based on the in-depth analysis of the experience of Russia's political history, has built into the Basic Law a powerful checks and balances mechanism as a guarantee of the protection of the interests of each individual citizen and of the State at large from the excesses of majoritarian democracy, and as an instrument for preventing conflicts or their uncontrollable escalation.

These discourses may also be relevant to the role of the Constitutional Court of the Russian Federation in defending the fundamentals of democracy as well as in the implementation of democracy. Formally, the Constitutional Court judges are not directly elected by the majority of the population but, instead, they are assigned by the Federation Council of the Federal Assembly according to Art. 1(g) of the Constitution of the Russian Federation. At the same time, however, the Constitutional Court must protect not only the Basic Law per se but also the constitutional rights and freedoms of each individual citizen where these rights are violated by the will of the majority, expressed in the law (according to Art. 4 of the Constitution, the

\footnotetext{
E.g., Barry R. Weingast, Capitalism, Democracy, and Countermajoritarian Institutions, 23(1) Supreme Court Economic Review 255 (2015).

7 For more detail, see Susan Alberts et al., Countermajoritarian Institutions and Constitutional Stability (April 2012) (Feb. 11, 2018), available at https://law.yale.edu/system/files/documents/pdf/Intellectual_ Life/LTW-Weingast.pdf.

8 Weingast 2015.
} 
Constitutional Court tests the constitutionality of a law applied or applicable in a particular case according to the procedure prescribed by federal law in response to the complaints of violation of citizens' constitutional rights and freedoms or upon court requests).

Conceptually, the very idea of setting up a special independent body to exercise constitutional control stems from the theory of separation of powers, the need for checks and balances, and the so-called broad understanding of the constitution as not only the body of basic procedural rules but also the core of the substantive law. Therefore, the guarantee of the effectiveness of a constitution should, first and foremost, be based on the possibility of unrestricted abolition of legal acts that contravene the constitution. At the same time, however, based on the meaning of the theory of separation of powers, the abolition of inappropriate acts may not be entrusted to the same entity that has passed these acts.

The institution of the sole Head of State (in the form in which it emerged, developed, and was enshrined in the 1993 Constitution) as well as the institution of constitutional justice are more than just the logical elements in the system of state power. The President and the Constitutional Court were the guardians of the project of designing and building the new State - the model of the desired future for Russia and, at the same time, the drivers of change in the country during the period of major systemic transformation.

\section{The President and the Constitutional Court as Institutions Fostering the Implementation of Constitutional Ideas}

Owing to the very existence and activities of the institutions of the Presidency and the Constitutional Court of the Russian Federation, the transitional chaos that emerged in the late 1980s and early 1990s was transformed into the modern reality day after day. In a situation not just of the lack of consensus but of the direct confrontation between elites and between branches of power, it was vital for the country to have a single center, a single leader capable of maintaining strategic direction and ensuring the implementation of reforms, including those in the constitutional and legal spheres. Thus, for many years the President and the Constitutional Court performed (and still are performing) a creative, constructive function, helping to implement in all spheres of life the norms and models enshrined in the Constitution of the Russian Federation.

During different historical periods, the constructive function of the Constitutional Court of the Russian Federation has taken different forms: first, promoting the legislative activity at the federal and regional levels in order to expedite the

9 See also the role of the Constitutional Court in ensuring the viability of constitutions: Dainius Žalimas, Viability of the Constitution and the Role of the Constitutional Court (May 2015) (Feb. 11, 2018), available at http://www.Irkt.lt/data/public/uploads/2015/10/viability-of-theconstitution-lvivroundtable.pdf. 
development of the new legal system in Russia; second, promoting the creation of new institutions and juridical relationships in keeping with the letter and spirit of the Constitution, protecting these institutions and the juridical relationship from attempts to distort or revise them; third, the so-called "negative" lawmaking, i.e. the efforts to screen off legal norms and practices that emerge in the course of the practical implementation of constitutional principles and models, and which are inappropriate from the standpoint of the letter and spirit of the Basic Law; ${ }^{10}$ and fourth, explaining and clarifying conceptual fundamentals of the new Russian Constitution to legislators and executors of the law, and thus enhancing the process of implementation of the Basic Law provisions to ensure practical outcomes are consistent with constitutional doctrine."

It should be noted that a legal phenomenon such as the Constitutional Court's stance ("legal position" - "pravovaya pozitsiya") that may be expressed in the form of a court ruling ("postanovleniye") or judgment of dismissal ("otkaznoye opredeleniye") plays an important role in the realization of its constructive function. The Constitutional Court's stances comprise important legal conclusions, principles, and general objectives resulting from the interpretation of the Constitution's letter and spirit. These conclusions (which are figuratively called "the crystallized law revealed by the court" ${ }^{\prime \prime 2}$ by Professor Gadis Gadzhiev, D. Leg. Sci.) directly affect the quality of lawmaking and law-enforcement practices, and the accuracy of the practical implementation of the constitutional models.

Apart from their constructive function, both the President and the Constitutional Court of the Russian Federation (after 1993) were (and still are) effectively performing the protective function in regard to both the Constitution and democracy at large.

In the early 1990s, it became clear that the untamed element of political freedom that emerged during the Gorbachev era had begun to negatively affect the speed and quality of development of the new foundations of statehood, and hinder the

10 There are different viewpoints concerning the usefulness of so-called "negative" lawmaking by the Constitutional Court, i.e. improving a legal system by removing some precepts from it through a declaration of their unconstitutionality. However, the important role of this mechanism cannot be denied at the early stage of formation of a legal system when only a timely "negative selection" was able to prevent the emergence of a whole block of legal acts that are inconsistent with the letter and spirit of the new Russian Constitution.

11 Sеe Клишас А.А. Конституционное правосудие в трансформирующихся обществах: опыт Российской Федерации // Материалы международной научно-практической конференции «Конституция как основа правовой системы государства в XXI веке. 30-31 октября 2008 года» [Andrey A. Klishas, Constitutional Justice in Transforming Societies: Experience of the Russian Federation in Materials of the International Research-to-Practice Conference "Constitution as the Foundation for the State's Legal System in the 21 $1^{\text {st }}$ Century. 30-31 October 2008"] 26 (Moscow: RUDN, 2009).

12 Sее Гаджиев Г.А. Правовые позиции Конституционного Суда Российской Федерации как источник конституционного права // Конституционное право: восточноевропейское обозрение. 1999. № 3(28). C. 81-95 [Gadis A. Gadzhiev, Stances of the Constitutional Court of the Russian Federation as a Source of Constitutional Law, 3(28) Constitutional Law: East European Review 81 (1999)]. 
advancement of social and economic reforms. Therefore, different safety mechanisms and special constitutional, political, and legal instruments had to be created to return the processes of change back onto a manageable track.

In fact, for quite a long time, the President of Russia as the supreme political arbiter and the Constitutional Court as the supreme judicial arbiter (metaphorically speaking) played the role of a steam valve, helping to reduce political pressures building up within society in a situation of confrontation between political elites where the forces on both sides of the barricades were almost equal in strength. The adoption of the law on referendums provided yet another effective instrument to preserve political stability throughout the entire 1990s.

To be fair, it should be mentioned that in the early 1990s when these institutions and mechanisms were being developed and put into practice there was simply no time for in-depth theoretical discussions on the nature of democracy or detailed modeling of the options of parliamentary structure depending on the vote threshold for the parties to be enshrined in the Constitution. At that time, the logic behind choosing any particular solution was actually determined by one objective only: to prevent the escalation of tensions and the breakup of the country. Experience shows that this goal was achieved.

Pondering the lessons of the dramatic events of the early 1990s, it has to be admitted that Przeworski's not-quite-scientific definition of democracy is fair to an extent: Przeworski called democracy"a system for processing conflicts without [political actors] killing one another."13

In this paradigm, the Head of State and the Constitutional Court and the law on referendums were the pivotal institutions and the most important protective mechanisms of democracy and the Constitution in every sense. Many times their status and the scope of possibilities available to them allowed the destructive energy of the conflicts to be redirected into a safe course, where, with an approximate balance of power, the parties decided to seek to win in court, conciliation committees, or referendums rather than on the barricades.

Throughout the 1990s, the President of the Russian Federation initiated a great number of conciliation procedures while the Constitutional Court tried dozens of cases concerned with key issues in the relationships between the branches of power, the development of federalism, and the provision of guarantees of equal voting rights throughout the entire country, among others. In the context of major changes, this helped, in no small measure, to keep the political and economic situation within the bounds of a "normal operational mode" and prevent various dangerous conflicts from becoming uncontrollable.

Moreover, when a politically divided State Duma failed for almost a decade to pass the most urgently needed legislation concerning the organization and authorities

\footnotetext{
13 Przeworski 1991, at 12, 95, 131.
} 
of the bodies of state power, federalism, electoral law, and protection of citizen's rights and freedoms, it was the rulings of the Constitutional Court of the Russian Federation that allowed this gap to be filled. The decisions of the Constitutional Court and the Court's stances expressed in these decisions helped to set up the elements of case law in Russia.

\section{The Constitutional Court: Applying the Framework}

During the period from 1995 through 2017, the Constitutional Court of the Russian Federation adopted more than 29,300 decisions (514 of which were rulings "postanovleniya"), most of which were concerned with the key issues of statebuilding and development of the new economic system and social relations.

When hearing the disputes (including the heated ones, stemming from practical state-building), the Constitutional Court not only formulated the key principles and parameters for building proper relationships between various state institutions, but also constantly expounded the fundamentals of the country's new constitutional system to society and political subjects.

It is interesting to compare the statistics and thematic distribution of the Constitutional Court's decisions during different periods of contemporary Russian history. The facts demonstrate that, staying away from politics, the Constitutional Court has responded fairly and objectively to high-profile issues of the state-building agenda.

For instance, issues associated with the interpretation of constitutional provisions were often addressed in the first years after the adoption of the new Basic Law, which is very understandable. Of the total number of Constitutional Court decisions made during the period from 1995 through 2017 and concerned with the interpretation of constitutional norms, most of the rulings were passed before 2000 .

At the same time, according to statistics published on the Constitutional Court's website, during the period from 2000 through 2017, three-quarters of the more than 40 Constitutional Court decisions on requests associated with the interpretation of provisions of the Basic Law provisions were judgments of dismissal. ${ }^{14}$

The few (nine) decisions on disputes of power between various authorities were also passed before 2000 .

Over 350 decisions of the Constitutional Court concerned various aspects of local self-government, and 95 percent of these decisions were passed during the period from 2000 through 2017.

The majority (more than 90\%) of Constitutional Court decisions concerning the formation of Russia's current electoral system and safeguarding citizens' right to vote in elections and referendums were also passed after 2000 (see Fig. 1).

\footnotetext{
14 See official website of the Constitutional Court of the Russian Federation: www.ksrf.ru.
} 
Fig. 1: Year-by-Year Distribution of Decisions of the Constitutional Court of the Russian Federation Concerned with Voting Legislation and Safeguarding Citizens' Right to Vote in Elections and Referendums ${ }^{15}$

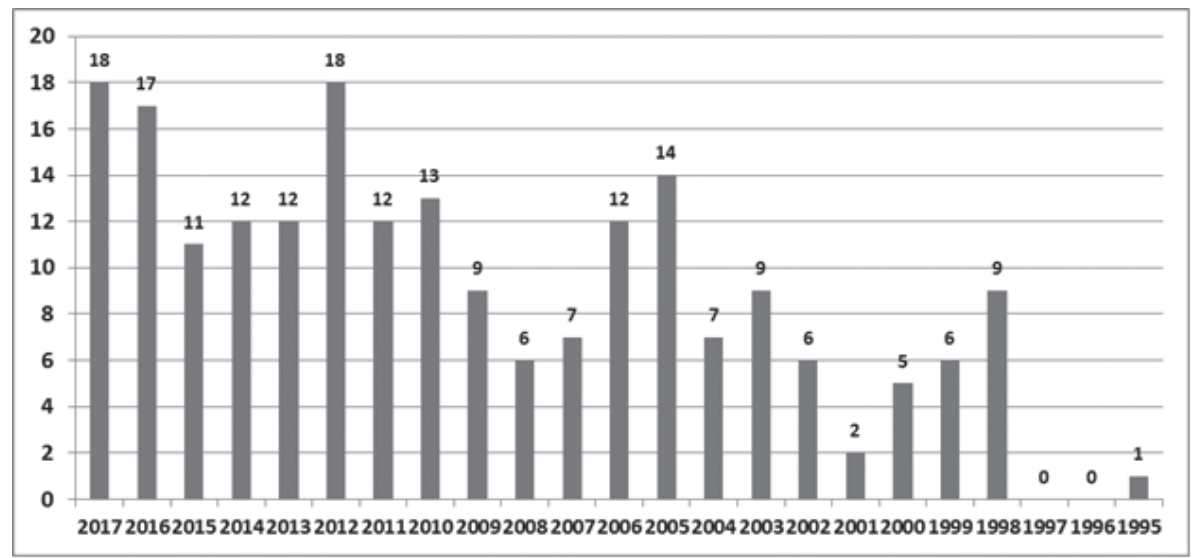

Throughout its entire existence following the adoption of the new Constitution of the Russian Federation, the Constitutional Court has directly helped to resolve conflicts and ensure a coherent interaction of public authorities, facilitated the development of the modern model of federalism and new economic relationships, affected the development of many areas of Russian law, and ensured the protection of citizens' rights and freedoms.

The most impressive and high-profile of the Constitutional Court cases have concerned the protection of citizens' fundamental rights and freedoms, such as the right to freedom of movement and choosing a place to stay and reside, and the right to labor remuneration and old-age social security benefits.

For instance, in 1996 the Constitutional Court reviewed complaints contesting license fees on hiring non-resident specialists, which had been established in some regions, and enshrinement of permissive registration of citizens at their place of residence, which was associated with payment of obligatory fees to the municipal budget. ${ }^{16}$

15 Source: official website of the Constitutional Court of the Russian Federation: www.ksrf.ru.

16 For instance, at the time of the hearing, according to the Moscow Law of 14 September 1994 "On the Levy Compensating for Municipal Budget Costs of the Development of Municipal Infrastructure and Provision of Social and Living Conditions for the Citizens Moving to Moscow to Take Up Permanent Residence," non-resident citizens who bought an apartment in Moscow and intended to live in this apartment were obliged to pay into the municipal budget a levy exceeding 5000-fold the minimum monthly wage. At the same time, the registration of citizens at the domicile belonging to them by right of property was strictly conditional on the payment of this levy.

For reference: the minimum monthly wage comprised 14,620 rubles in 1994, and 63,250 rubles by the time of the hearing (the spring of 1996). 
As noted in the Constitutional Court's ruling, the right to choose a place of residence is part of the freedom of personal self-determination. Public authorities are only mandated to register the result of the expression of a citizen's free will in choosing his or her place of residence.

The citizens' right to choose their place of residence may only be limited by federal law. According to the Constitutional Court, the registration of Russian Federation citizens at the place of their residence by notification, established in the then effective Law of the Russian Federation of 25 June 1993 No. 5242-I "On the Right of Citizens of the Russian Federation to the Freedom of Movement, the Choice of a Place of Stay and Residence within the Russian Federation, ${ }^{117}$ is a permissible restriction of this right. At the same time, in contrast to the federal legislation, the Moscow and Moscow Oblast authorities' requirement of obligatory payment of fees to the regional budget as a precondition for a citizen's registration at the dwelling fully owned by the citizen established the permissive registration and, therefore, was ruled unconstitutional by the Constitutional Court.

The Constitutional Court emphasized that:

the implementation of [the] constitutional right to choose the place of residence may not be conditional upon the payment (or non-payment) of any taxes and levies, as basic rights of the citizens of the Russian Federation are guaranteed by the Constitution of the Russian Federation without any fiscal conditions attached. Therefore, the denial of registration due to [a] citizen's failure to perform his or her duties to pay taxes and other levies is unconstitutional (Art. 27(1)). ${ }^{18}$

In 1998, the Constitutional Court of the Russian Federation defended the citizens' right to receive retirement pensions to which they are entitled regardless of whether the pensioner changed his or her permanent residence to a foreign country before or after 1 July 1993. According to the Constitutional Court:

[T]he citizen's rights in the sphere of retirement benefits are derived from his employment or other socially beneficial activities. Old age, long-service and other pensions awarded in connection with employment or other activities

17 Закон Российской Федерации от 25 июня 1993 г. № 5242-І“О праве граждан Российской Федерации на свободу передвижения, выбор места пребывания и жительства в пределах Российской Федерации," Собрание законодательства РФ, 1993, № 32, ст. 1227 [Law of the Russian Federation No. 5242-I of 25 June 1993. On the Right of Citizens of the Russian Federation to the Freedom of Movement, the Choice of a Place of Stay and Residence within the Russian Federation, Legislation Bulletin of the Russian Federation, 1993, No. 32, Art. 1227].

18 Постановление Конституционного Суда РФ от 4 апреля 1996 г. № 9-П, Собрание законодательства РФ, 1996, № 16, ст. 1909 [Ruling of the Constitutional Court of the Russian Federation No. 9-P of 4 April 1996, Legislation Bulletin of the Russian Federation, 1996, No. 16, Art. 1909]. 
recognized by the legislator as socially beneficial are earned by previous work or service, by performing socially important duties. This determines the content and nature of the state's duties towards those citizens who have acquired the right to such pensions. Discontinuation of accrual and payment of retirement pensions to the citizens who have moved abroad to take up permanent residence, for the period of their living abroad is the limitation of [the] constitutional right to social security guaranteed by Art. 39(1) of the Constitution of the Russian Federation.

By virtue of Art. 55(3) of the Constitution of the Russian Federation, human and civil rights and freedoms may only be restricted to the extent necessary for the purposes of protecting the fundamentals of the constitutional system, morals, health, rights and legitimate interests of other persons, for ensuring the country's defense and state security. The restriction of human and civil rights and freedoms established by the Law of the Russian Federation "On the Payment of Pensions to Citizens Leaving the Russian Federation to Take Up Permanent Residence Abroad" is inconsistent with these purposes and, thus, contravenes Art. 55(3) of the Constitution of the Russian Federation. ${ }^{19}$

It should be noted that modern democratic states advocating the universality of various democratic rights and liberties often come to a standstill when the cases of competing, equally important and valuable but, at the same time, formally conflicting principles and values are considered; for instance:

- inviolability of the territorial integrity of the state, and exercising the right of nations to self-determination;

- sovereignty of the federal state and autonomy of its constituent entities;

- guarantees of equal protection of public and private interests;

- guarantees of economic freedom and the social nature of the state; and

- the employer's equally important duties to remunerate labor and pay legitimate taxes and levies to the State (even in a situation of financial and economic crisis).

Many experts regard equally protected but, at the same time, "competing" constitutional principles either as an insolvable problem or as a deliberate use of double standards that allows values to be prioritized depending on political expediency. One must admit, however, that all of these formally opposing values and principles are equally important for individuals, society, and the State. The art of managing social development consists in fitting practical policy solutions into the narrow "corridor of possibilities" and charting a political course between the Scylla and Charybdis of sometimes opposing but equally important values and principles.

19 Постановление Конституционного Суда РФ от 15 июня 1998 г. № 18-П, Собрание законодательства РФ, 1998, № 25, ст. 3003 [Ruling of the Constitutional Court of the Russian Federation No. 18-P of 15 June 1998, Legislation Bulletin of the Russian Federation, 1998, No. 25, Art. 3003]. 
At the same time, in each particular case the trajectory can bend towards one side or the other, but it is important to be able to timely identify an unwanted bias, prevent or correct dangerous excesses that can upset the balance of interests and disrupt social harmony.

Practitioners know that no universal solutions exist and, in changing circumstances, in a changing world, what seems fair and right in one situation may be harmful and dangerous in another. Tribute should be paid to the Constitutional Court of the Russian Federation: in the most difficult situation where public consensus was lacking and there was a strong political opposition within the Federal Assembly of the Russian Federation, the Constitutional Court undertook a mission of not only expounding the meaning of constitutional provisions but also consistently showing to all branches of power the ways for finding an effective balance between equal constitutional values that define the contours of the new political reality and the "corridor" of legislative possibilities.

Thus, for instance, in its Ruling of 23 December 1997 No. 21-P on the case of testing the constitutionality of Art. 55(2) of the Civil Code of the Russian Federation ("On the Fundamentals of the Tax System in the Russian Federation"), the Constitutional Court pointed out to the legislator that:

[T]he constitutional duties to remunerate labor and pay lawfully established taxes and levies may not be opposed to each other, since placing a rigid priority on only one of these duties means the impossibility of exercising and, hence, the derogation of equally protected rights and legitimate interests of one or other groups of citizens, which also contravenes Art. 55(2) of the Constitution of the Russian Federation. ${ }^{20}$

And in its well-known ruling in the "Chechen case," the Constitutional Court provided a detailed explanation of how the constitutional principle of state integrity and the right of nations to self-determination are consistent with each other. The Constitutional Court emphasized that the integrity of the State is one of the fundamentals of the constitutional system of the Russian Federation, an important condition of equal legal status for all citizens regardless of their place of residence, one of the guarantees of their constitutional rights and liberties. The constitutional objective of the preservation of the integrity of the Russian State is consistent with universally accepted international norms on a people's right to self-determination. It follows from the Declaration on Principles of International Law concerning Friendly Relations and Co-operation among States in accordance with the Charter of the United Nations, adopted on 24 October 1970, that:

20 Постановление Конституционного Суда РФ от 23 декабря 1997 г. № 21-П, Собрание законодательства РФ, 1997, № 2, ст. 5930 [Ruling of the Constitutional Court of the Russian Federation No. 21-P of 23 December 1997, Legislation Bulletin of the Russian Federation, 1997, No. 2, Art. 5930]. 
[E]xercising people's right of self-determination shall not be "construed as authorizing or encouraging any action which would dismember or impair, totally or in part, the territorial integrity or political unity of sovereign and independent States conducting themselves in compliance with the principle of equal rights and self-determination of peoples."21

These and many other stances of the Constitutional Court are of profound theoretical and, at the same time, direct practical importance for both contemporary Russia and the entire global community which sometimes only begins to seek answers to challenges that have already become history for Russia.

As a result of the activities of this institution, which is extremely important for ensuring the Constitution's viability, the rigid legal contours necessary for developing the new system of Russian law were being unflinchingly created. The trajectories were set for all participants in the legislative process to move forward so that the legal reality consistent with the ideas, norms, and principles stipulated in the country's new Basic Law would be born in practice. The fact that, at present, political life is relatively stable does not mean that the constructive and protective role of the Constitutional Court has been exhausted.

\section{Conclusion}

The history of the new Russian state and law formation provides many arguments to support the hypothesis that the viability of democratic constitutions, as well as political stability, increases if the constitutional model provides for the existence of countermajoritarian institutions and ensures their effective action. It can be argued that in post-crisis societies, the constitutional model of "countermajoritarian democracy" ensures stability and sustainable development of the new political system more effectively and reliably than attempts to implement the "pure version" of classical majoritarian democracy.

The Russian Constitution of 1993, formed on a model with countermajoritarian features, has proved its evidence-based effectiveness and can serve as an example of good practice in designing a viable democratic constitution.

\section{References}

Alberts S. et al. Democratization and Countermajoritarian Institutions Power and Constitutional Design in Self-Enforcing Democracy in Comparative Constitutional Design (T. Ginsburg (ed.), Cambridge: Cambridge University Press, 2012).

21 Постановление Конституционного Суда РФ от 31 июля 1995 г. № 10-П, Собрание законодательства РФ, 1995, № 33, ст. 3424 [Ruling of the Constitutional Court of the Russian Federation No. 10-P of 31 July 1995, Legislation Bulletin of the Russian Federation, 1995, No. 33, Art. 3424]. 
Bickel A.M. The Least Dangerous Branch: The Supreme Court at the Bar of Politics ( $2^{\text {nd }}$ ed., New Heaven and London: Yale University Press, 1986).

Diamond L. Developing Democracy: Toward Consolidation (Baltimore: Johns Hopkins University Press, 1999).

Elkins Z. et al. The Endurance of National Constitutions (New York: Cambridge University Press, 2009).

Linz J.J. \& Stepan A. Problems of Democratic Transition and Consolidation (Baltimore: Johns Hopkins University Press, 1996).

Mittal S. \& Weingast B.R. Self-Enforcing Constitutions: With an Application to Democratic Stability in America's First Century, 29(2) Journal of Law, Economics, and Organization 278 (2013).

Przeworski A. Democracy and the Market: Political and Economic Reforms in Eastern Europe and Latin America (New York: Cambridge University Press, 1991).

Weingast B.R. Capitalism, Democracy, and Countermajoritarian Institutions, 23(1) Supreme Court Economic Review 255 (2015).

Weingast B.R. The Political Foundations of Democracy and the Rule of Law, 91(2) American Political Science Review 245 (1997).

\section{Information about the authors}

Sergey Shakhray (Moscow, Russia) - Vice-Rector, Professor, Lomonosov Moscow State University (1 Leninskie Gory, GSP-1, Moscow, 119991, Russia; e-mail: s9895929@ yandex.ru).

Svetlana Popova (Moscow, Russia) - Leading Researcher, Institute of SocioPolitical Research of the Russian Academy of Sciences (6/1 Fotievoy St., Moscow, 119333, Russia; e-mail:sv-2002-1@yandex.ru). 